\title{
Optimum size in grid soil sampling for variable rate application in site-specific management
}

\author{
Marcos Rafael Nanni ${ }^{1 *}$; Fabrício Pinheiro Povh²; José Alexandre Melo Demattê3; Roney Berti \\ de Oliveira ${ }^{1}$; Marcelo Luiz Chicati ${ }^{1}$; Everson Cezar ${ }^{1}$ \\ ${ }^{1}$ UEM - Depto. de Agronomia - Av. Colombo, 5790 - 87020-900 - Maringá, PR - Brasil. \\ ${ }^{2}$ USP/ESALQ - Programa de Pós-Graduação em Fitotecnia, Av. Pádua Dias, 11 - 13418-900 - Piracicaba, SP - \\ Brasil. \\ ${ }^{3}$ USP/ESALQ - Depto. de Ciência do Solo, Av. Pádua Dias, 11 - 13418-900 - Piracicaba, SP - Brasil. \\ *Corresponding author <mrnanni@uem.br>
}

\begin{abstract}
The importance of understanding spatial variability of soils is connected to crop management planning. This understanding makes it possible to treat soil not as a uniform, but a variable entity, and it enables site-specific management to increase production efficiency, which is the target of precision agriculture. Questions remain as the optimum soil sampling interval needed to make site-specific fertilizer recommendations in Brazil. The objectives of this study were: i) to evaluate the spatial variability of the main attributes that influence fertilization recommendations, using georeferenced soil samples arranged in grid patterns of different resolutions; ii) to compare the spatial maps generated with those obtained with the standard sampling of 1 sample ha $^{-1}$, in order to verify the appropriateness of the spatial resolution. The attributes evaluated were phosphorus $(\mathrm{P})$, potassium $(\mathrm{K})$, organic matter $(\mathrm{OM})$, base saturation $(\mathrm{V} \%)$ and clay. Soil samples were collected in a $100 \times 100 \mathrm{~m}$ georeferenced grid. Thinning was performed in order to create a grid with one sample every 2.07, 2.88, 3.75 and 7.20 ha. Geostatistical techniques, such as semivariogram and interpolation using kriging, were used to analyze the attributes at the different grid resolutions. This analysis was performed with the Vesper software package. The maps created by this method were compared using the kappa statistics. Additionally, correlation graphs were drawn by plotting the observed values against the estimated values using cross-validation. $\mathrm{P}, \mathrm{K}$ and $\mathrm{V} \%$, a finer sampling resolution than the one using 1 sample $\mathrm{ha}^{-1}$ is required, while for $\mathrm{OM}$ and clay coarser resolutions of one sample every two and three hectares, respectively, may be acceptable.

Key words: soil attributes, grid sampling, kriging, cross-validation, kappa statistic
\end{abstract}

\section{Tamanho ideal em grades de amostragem de solos para aplicação em taxa variável em manejo localizado}

\begin{abstract}
RESUMO: A importância de compreender a variabilidade espacial do solo está conectada ao planejamento do manejo das culturas. Este entendimento faz com que seja possível tratar o solo não como uma entidade uniforme, mas variável, e permite o gerenciamento de sítios específicos para aumentar a eficiência de produção, que é o objetivo da agricultura de precisão. Questões relacionadas com a otimização do intervalo de amostragem do solo se faz necessário para a realização das recomendações de adubações no Brasil. Os objetivos deste estudo foram: i) avaliar a variabilidade espacial dos principais atributos que influenciam as recomendações de adubação, usando amostras de solos georreferenciadas dispostas em padrões de grades de diferentes resoluções; ii) comparar os mapas espaciais gerados com o mapa padrão obtido com amostragem de 1 amostra ha ${ }^{-1}$, a fim de verificar a adequação da resolução espacial. Os atributos avaliados foram fósforo $(\mathrm{P})$, potássio $(\mathrm{K})$, matéria orgânica $(\mathrm{MO})$, saturação por bases (V\%) e argila. As amostras de solos foram coletadas numa grade de $100 \times 100 \mathrm{~m}$ e georreferenciadas. Um desbaste foi realizado, criando-se uma grade com 1 amostra a cada 2,07, 2,88, 3,75 e 7,20 ha. Técnicas de geoestatística, como semivariograma e interpolação usando krigagem, foram utilizadas para analisar os atributos nas grades com diferentes resoluções. Esta análise foi realizada com o programa computacional Vesper. Os mapas criados por este método foram comparados utilizando-se a estatística kappa. Além disso, gráficos de correlação foram construídos plotando-se os valores observados pelos valores estimados utilizando-se a validação cruzada. Para $\mathrm{P}, \mathrm{K} \mathrm{e} \mathrm{V} \%$, uma amostragem de resolução mais fina do que aquela usando $1 \mathrm{amostra} \mathrm{ha}^{-1}$ foi necessária, enquanto que para MO e argila, resoluções mais grosseiras de uma amostra ou dois em dois e três hectares, respectivamente, pode ser aceitável.
\end{abstract}

Palavras-chave: atributos dos solos, grade de amostragem, krigagem, validação cruzada, estatística kappa

\section{Introduction}

Many studies on spatial variability are carried out in a pedological context, where soil description is based on genetic horizons. Applications such as land evaluation should also consider the types of variation that are induced within a given soil by its management.

Different types of management can often have a major impact on soil behavior than soil genesis (Burrough et al., 1994). Soil management can change the chemical, physical, 
mineralogical and biological attributes and mainly impact the shallow soil (Corá et al., 2004). Clearly, different land uses may cause different effects on soil properties, and some chemical or physical properties may be more sensitive than others (Trangmar et al., 1985).

The importance of understanding the spatial variability of soil is connected to crop management planning. This understanding makes it possible to treat the soil not as a uniform but variable entity and enables the use of site-specific management which increases production efficiency.

Comparisons of grid soil sampling on several scales have been discussed in the literature (Mallarino and Wittry, 2004; Flowers et al., 2005). Regardless of the technique used, grid soil sampling at high resolutions (i.e., 1 sample every 0.4 ha or less) is time consuming and cost-intensive. Gotway et al. (1996) evaluated the organic matter in a Pachic Haplustoll soil, 53 ha irrigated corn field in Nebraska-USA with sample spacing from 24 to $72 \mathrm{~m}$, and the smaller the distance between samples, the better prediction values using kriging.

Questions remain as to the optimum soil sampling grid resolution for making site-specific fertilizer recommendations in Brazil. Actually, each field has its own optimum sampling resolution, which is based on its intrinsic variability, but soil samples are commonly collected at spacings from 1 sample $\mathrm{ha}^{-1}$ to 1 sample every 5 ha without any justification. Many times, the choice of resolution is motivated solely by economical and practical reasons.

One reason for performing this study is to show that a single size of a grid sampling cannot be used in all areas, as made today commercially in Brazil, mainly by collecting samples every 2 or 3 ha. Demattê et al. (2006) established that modules with 4.0 ha can be the most suitable for soil sampling and fertilizer recommendations for the sugarcane crop in the São Paulo state, established when the cost benefit of sampling and inputs are taken into account.

The idea is to guide further research in order to create management zones or use other tools to characterize the spatial variability that are faster and cheaper, such as soil classification, soil electrical conductivity, yield maps etc.

The objectives of this study were: i) to evaluate the spatial variability of the main attributes that influence fertilization recommendations using georeferenced soil samples arranged in grid patterns of different resolutions, and ii) to compare the spatial maps generated with those obtained with the standard sampling of 1 sample ha ${ }^{-1}$, in order to verify the appropriateness of the spatial resolution.

\section{Material and Methods}

The study area is located in the Rafard, in the southwestern portion São Paulo state, Brazil, in a region called the Paleozoic depression. The field, delimited by the geographic coordinates $23^{\circ} 00^{\prime}$ - $22^{\circ} 58^{\prime}$ S; $47^{\circ} 39^{\prime}-47^{\circ} 37^{\prime} \mathrm{W}$, has an extension of 184 ha with high soil variability and is cultivated with sugarcane (Nanni et al., 2004). These areas have been historically used for the cultivation of sugarcane, with application of organic and chemical fertilizers during planting of sugarcane and in coverage (ratton crops), made when necessary to correct acidity or increase base saturation.
Geologically, the area is situated in the Itarare formation of the Tubarão group. This formation is a complex association of lithofacies, mostly sedimentary, that appears in fairly fast vertical and horizontal successions. The predominant lithologies consist of immature psammite with heterogeneous granulation, leading to feldspathic psammite and even arkosic sandstone. Concomitant with the Itarare formation lithology, there are eruptive dike elements of the Serra Geral formation, which comprise the intrusive bodies of the tholeitic basalts (Nanni and Demattê, 2006).

Predominate in the region, as in the peripheral depression, tabular hills, with slopes softened, where the altitude is typically between 500 and 700 meters. The regional topography is characterized by presenting series of low hills of forms and smoothed with less flattened tops. The area boasts of rolling hills topography of small amplitude of rectilinear profile with continuous and convex tops and not very extensive and moderately flattened.

Out of the 12 orders of Soil Taxonomy (Soil Survey Staff, 1998), six were found in this farm: Oxisols, Entisols, Alfisols, Ultisols, Inceptisols and Molisols (Costa and Nanni, 2006), which were established from the following subgroups: Typic Haplorthox; Typic Udorthent; Typic Udifluvent; Rhodic Paleudalf; Arenic Abruptic Paleudalf; Typic Paleuldult; Typic Eutrochrept; Typic Dystrochrept; Typic Argiudoll.

The region has a mesothermic climate (Cwa, according to Köppen Classification), which consists of dry winters and wet summers. The average temperature in July is $18^{\circ} \mathrm{C}$ and $22^{\circ} \mathrm{C}$ in February. Usually, the annual rainfall in this region is between 1,100 to $1,700 \mathrm{~mm}$.

Soil samples were collected at the nodes of a regular grid of $100 \times 100 \mathrm{~m}$ grid, from the 0 to $0.20 \mathrm{~m}$ top layer, consisting of five randomly sampled cores within a circle of 1 $\mathrm{m}$ radius (Figure 1). The grid was generated using an infrared distance meter, eliminating errors that would result from using a GPS receiver. The grid, including 184 points, was georeferenced with a 10-parallel-channel L1, C/A code GPS receiver (Magellan, PROMark-CM) with $15 \mathrm{~mm}+3 \mathrm{ppm}$ (static centimeter horizontal) differential accuracy.

Soil analyses were carried out to determine sand, silt, and clay contents using the densimeter method (Camargo et al., 1986). The exchangeable bases $\left(\mathrm{mmol}_{\mathrm{c}} \mathrm{dm}^{-3}\right)$ from calcium

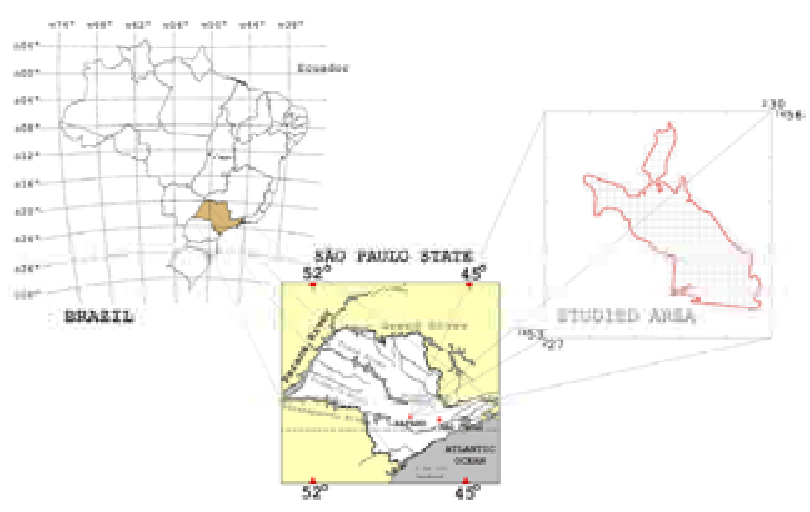

Figure 1 - Location of the study area and soil sampling grid representation (1 sample ha ${ }^{-1}$ ). 
(Ca), magnesium $(\mathrm{Mg})$, and potassium $(\mathrm{K})$ sources and the sum of the bases (S) were determined according to Raij and Quaggio (1989). The phosphorus (P) content $\left(\mathrm{mg} \mathrm{dm}^{-3}\right)$ was extracted by the Mehlich-1 extraction method and determined using the colorimetric method of Embrapa (1997). Organic matter $(\mathrm{OM})$, total and effective acidity (determined by $1 \mathrm{M}$ calcium acetate $-\mathrm{Ca}\left(\mathrm{CH}_{3} \mathrm{COO}\right)_{2} \mathrm{H}_{2} \mathrm{O}$ and $1 \mathrm{M} \mathrm{KCl}$ titulometric method, respectively), $\mathrm{pH}$ in water and in $\mathrm{KCl}$, cation exchange capacity (CEC), the values of base saturation (V\%) and aluminum $(\mathrm{Al})(\mathrm{m} \%)$ were calculated according to Embrapa (1997).

Sample points thinning was performed from the 1 sample $\mathrm{ha}^{-1}$ grid to create new grids with resolution of 1 sample every 2.07, 2.88, 3.75 and 7.20 ha (Figure 2).

Descriptive statistics, including mean, median, minimum, maximum, skewness, kurtosis, standard deviation and coefficient of variation, were calculated. Geostatistics was used to model the semivariograms, which express the spatial dependence among samples, and ordinary kriging was applied to predict the values of the variables in unsampled regions based on nearby sample data.

The experimental semivariograms were manually adjusted to an isotropic spherical model with a number of lags set at $50 \%$ of the maximum distance using the software Vesper 1.62 (Minasny et al., 2005). The same software was used to perform ordinary punctual kriging with a $20-\mathrm{m}$ mesh grid.

Two types of analyses were conducted, one involving the kappa index of agreement and the other using cross-
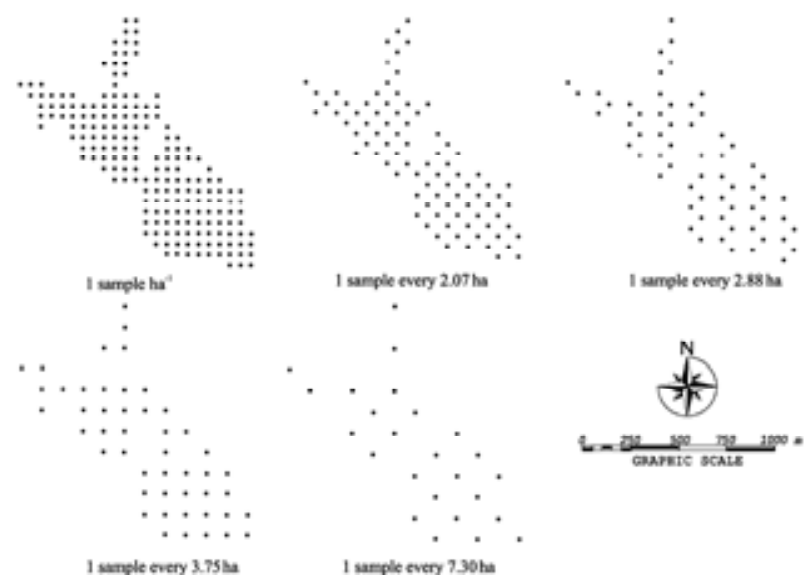

Figure 2 - Grid densities generated by thinning the 1 sample $\mathrm{ha}^{-1}$ grid. validation with correlation graphs. Maps were classified using natural breaks (Jenks, 1967), which determine the best arrangement of the values into classes by comparing the sums of the squared difference between the observed values within each class and class means. This classification identifies break points by picking up the class breaks that best group similar values and maximize the differences between classes.

Kappa index (Cohen, 1960) was calculated in an electronic spreadsheet developed using Microsoft Excel ${ }^{\circledR}$, to evaluate the degree of spatial association between the maps obtained from the 1 sample ha ${ }^{-1}$ sampling and the ones generated from the wider grids.

\section{Results and Discussion}

The mean and median values were very different for some variables, such as $\mathrm{P}$ and $\mathrm{K}$, which were strongly positively skewed and with very high values of kurtosis. The CVs $(\%)$ were moderate $(12 \%<\mathrm{CV}<60 \%)$ for $\mathrm{OM}, \mathrm{V} \%$ and clay, whereas high for $\mathrm{P}$ and $\mathrm{K}$ according to the criteria of Warrick and Nielsen (1980), (Table 1).

All experimental variograms were fitted using a spherical model with the exception of the one of $\mathrm{P}$ at the scale of 1 sample every 7.20 ha, which showed a pure nugget effect. Cross-validation, performed for all the attributes at the scale of 1 sample $\mathrm{ha}^{-1}$, produced the correlation coefficient of 0.19 for P; 0.47 for $\mathrm{K} ; 0.53$ for $\mathrm{V} \% ; 0.72$ for $\mathrm{OM}$ and 0.84 for clay. Such values were evaluated as poor (values under 0.5 ), moderate to good (values from 0.50 to 0.75 ) or excellent (values above 0.75).

The standard sampling of 1 sample $\mathrm{ha}^{-1}$ can be deemed appropriate for organic matter and clay, whereas $\mathrm{P}, \mathrm{K}$ and $\mathrm{V} \%$ require further sampling at a finer scale than 1 sample ha ${ }^{-1}$. Moreover, the semivariograms, separately for organic matter and clay, had similar ranges for all grids (Table 2) and some main spatial structures occurred in the maps at any spatial scale (Figure 3 and Figure 4).

The estimated maps for organic matter and clay were also analyzed through the kappa statistic by comparing the 1 sample $\mathrm{ha}^{-1}$ grid with the others, using the same five classes, previously defined by natural breaks. The results of the test of spatial agreement (Table 3) can be interpreted in following way: the values of kappa significantly different from zero and lower than 0.4 indicate poor agreement; between 0.4 and less than 0.7 fair agreement and greater than 0.7 good agreement. Clay could be sampled even at 1 sample every 2.88 ha,

Table 1 - Descriptive statistics for soil attributes.

\begin{tabular}{lrrrrrrrr}
\hline \multirow{2}{*}{ Grid Size } & \multicolumn{7}{c}{ Descriptive Statistics } \\
\cline { 2 - 9 } & Mean & Median & Min & Max & Skewness & Kurtosis & CV (\%) & Standard deviation \\
\hline P & 20.5 & 10.0 & 1.0 & 173.0 & 3.1 & 10.6 & 143.4 & 29.3 \\
K & 2.2 & 1.6 & 0.1 & 10.6 & 2.0 & 6.0 & 72.0 & 1.6 \\
OM & 17.8 & 15.0 & 1.0 & 52.0 & 0.9 & 0.7 & 59.0 & 10.6 \\
\hline V\% & 69.2 & 71.4 & 13.8 & 96.9 & -0.7 & 0.0 & 26.8 & 18.6 \\
Clay & 322.7 & 294.5 & 60.0 & 678.0 & 0.2 & -1.3 & 55.5 & 179.0 \\
\hline
\end{tabular}




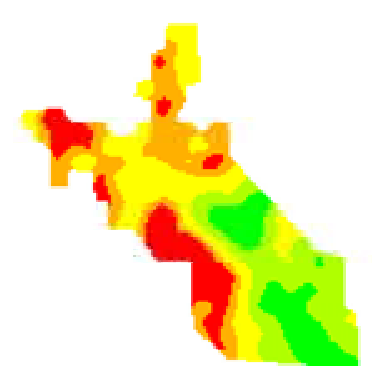

I sample ha ${ }^{-1}$

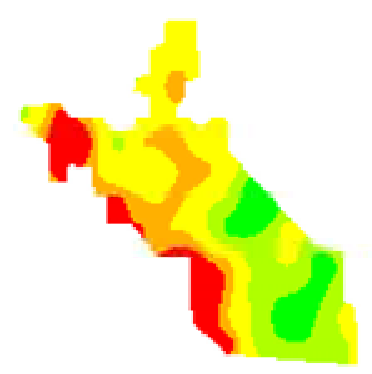

I sample every 3.75 ha

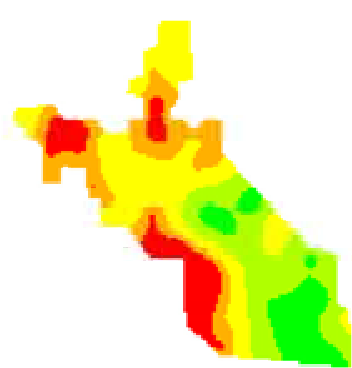

1 sample every 2.07 ha

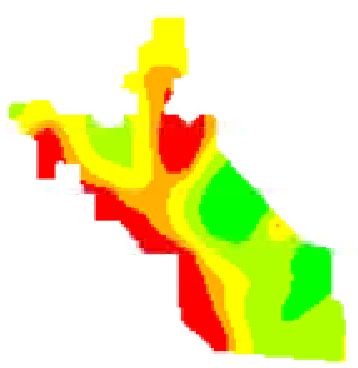

1 sample every $7,30 \mathrm{ha}$

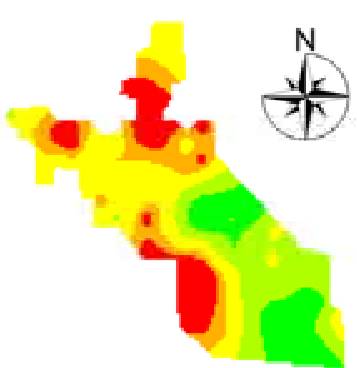

1 sample every 2.88 ha

$28-49$

$20-28$

$13-20$

$10-13$

$2-10$

Q $-\frac{250 \quad 500 \quad 750 \quad 1000}{\text { GRAPHIC SCAL.F }}=$

Figure 3 - Kriged maps of organic matter $\left(\mathrm{g} \mathrm{dm}^{-3}\right)$ classified by natural breaks.
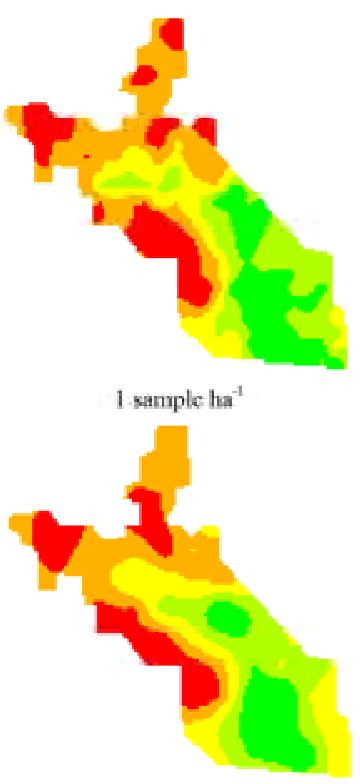

1 sample every 3.75 ha
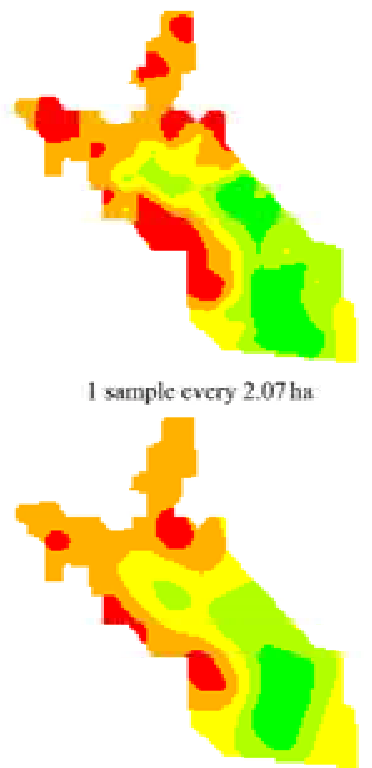

I sample every 7.30 ha

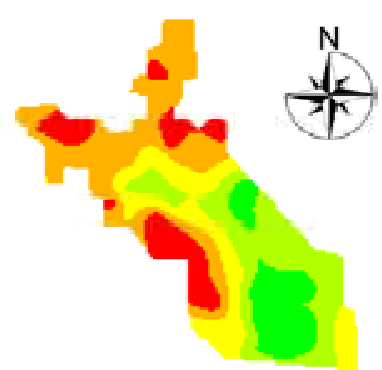

1 sample every 2.88 ha

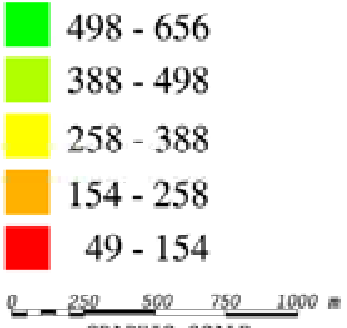

GRAPHIC SCALF

Figure 4 - Kriged maps of clay $\left(\mathrm{g} \mathrm{dm}^{-3}\right)$ classified by natural breaks.

whereas organic matter with a grid of 1 sample every 2.07 ha (Table 3). This result was partly expected, because attributes that are more related to soil type and topography are characterized by spatial variability at longer ranges than the ones more affected by management practices as $\mathrm{P}$ and K. Crop and soil practices, site-specific management such as cropping system, tillage, nutrient removal in harvested products and the application method and rate of fertilizer or manure have a marked influence on how nutrient supplies change over time (Mallarino and Wittry, 2004; Flowers et al., 2005).
In order to verify the possibility to perform a wider sampling for clay and organic matter, it was necessary to analyze the loss of accuracy due to the increase of the grid - mesh through a cross-validation. Figures 5 and 6 show the regression lines and the related equations at the different sampling scales for OM and clay, respectively. These results might be so interpreted that in the study site a coarse sampling of 1 sample every 3.75 ha and 1 sample every 7.2 ha might be appropriate for $\mathrm{OM}$ and clay, respectively. However, Ferguson and Hergert (1994) suggest that soil sampling must be made on a grid with one sample every $0.4 \mathrm{ha}$. On the fields ex- 
Table 2 - Adjustment of the semivariograms for the soil attributes.

\begin{tabular}{|c|c|c|c|c|}
\hline \multirow{2}{*}{ Grid Size } & \multicolumn{4}{|c|}{ Models and Parameters } \\
\hline & Attribute & Nugget Effect (Co) & Semivariance $(\mathrm{Co}+\mathrm{C})$ & Range (a) meters \\
\hline \multirow{5}{*}{1.00} & Phosphorus & 694.10 & 1034.10 & 722 \\
\hline & Potassium & 0.91 & 2.68 & 353 \\
\hline & Base Saturation (V\%) & 152.50 & 438.30 & 1579 \\
\hline & Organic Matter (OM) & 26.30 & 115.50 & 691 \\
\hline & Soil Clay & 1811.80 & 25335.80 & 608 \\
\hline \multirow{5}{*}{2.07} & Phosphorus & 856.00 & 1110.80 & 657 \\
\hline & Potassium & 0.51 & 2.08 & 276 \\
\hline & Base Saturation (V\%) & 117.30 & 460.10 & 1698 \\
\hline & Organic Matter (OM) & 29.90 & 114.50 & 707 \\
\hline & Soil Clay & 8.20 & 24494.20 & 628 \\
\hline \multirow{5}{*}{2.88} & Phosphorus & 741.10 & 1507.10 & 630 \\
\hline & Potassium & 0.00 & 2.56 & 282 \\
\hline & Base Saturation (V\%) & 133.30 & 509.40 & 2183 \\
\hline & Organic Matter (OM) & 20.10 & 143.60 & 727 \\
\hline & Soil Clay & 306.70 & 25604.70 & 643 \\
\hline \multirow{5}{*}{3.75} & Phosphorus & 723.50 & 1133.80 & 1040 \\
\hline & Potassium & 0.95 & 1.92 & 2045 \\
\hline & Base Saturation (V\%) & 82.40 & 403.20 & 1606 \\
\hline & Organic Matter (OM) & 11.80 & 106.60 & 656 \\
\hline & Soil Clay & 13.10 & 25192.10 & 550 \\
\hline \multirow{5}{*}{7.20} & Phosphorus & --- & --- & --- \\
\hline & Potassium & 0.65 & 2.05 & 1525 \\
\hline & Base Saturation (V\%) & 51.20 & 384.50 & 1195 \\
\hline & Organic Matter (OM) & 0.09 & 144.20 & 669 \\
\hline & Soil Clay & 18.10 & 24300.10 & 506 \\
\hline
\end{tabular}

Table 3 - Kappa index comparing the one sample ha ${ }^{-1}$ grid with the other grids.

\begin{tabular}{ccc}
\hline Grid Size & OM & Clay \\
\hline 2.07 & $0.76^{*}$ & $0.79^{*}$ \\
2.88 & $0.65^{*}$ & $0.70^{*}$ \\
3.75 & $0.56^{*}$ & $0.60^{*}$ \\
7.20 & $0.49^{*}$ & $0.53^{*}$ \\
\hline
\end{tabular}

${ }^{*} p \leq 0.05$.

pected to have low variability 1 sample every 0.8 to 1.0 ha may be acceptable, but the authors do not recommend grid sampling with a density wider than 1 sample $\mathrm{ha}^{-1}$.

Cahn et al. (1994) and Cambardella and Karlen (1999) reported that the correct sampling scale varies not only from field to field but also depends on the soil fertility parameters. Consequently, the optimal sampling density for a field is usually unknown before sampling. However, soil testing costs have to remain low and sampling must be economically feasible. One way to reduce the number of necessary samples is to partition the field in specific management zones and then use a stratified sampling. The number and the size of these zones will depend on soil variability. For example, instead of collecting 1 sample ha ${ }^{-1}$, the farmer could collect one sample in each zone in which the field was partitioned in. Yield maps are commonly used to define within - field zones with different soil productivity. This may be a useful criterion to delineate specific management zones because different yield levels likely require different amounts of nutrients and activate different nutrient trends in the soil. However, yield maps over at least three years are needed to delineate site-specific management zones according to Mallarino and Wittry (2004). Many other tools can also be used to optimize soil sampling, such as soil electrical conductivity measurement and NDVI (Normalized Difference Vegetation Index) determination from ground-based optical sensors and satellite images, respectively.

\section{Conclusions}

For the evaluated sugarcane field a sampling density of 1 sample ha ${ }^{-1}$ was not sufficient to capture the spatial 
OM - 1 sample each 2.07 ha

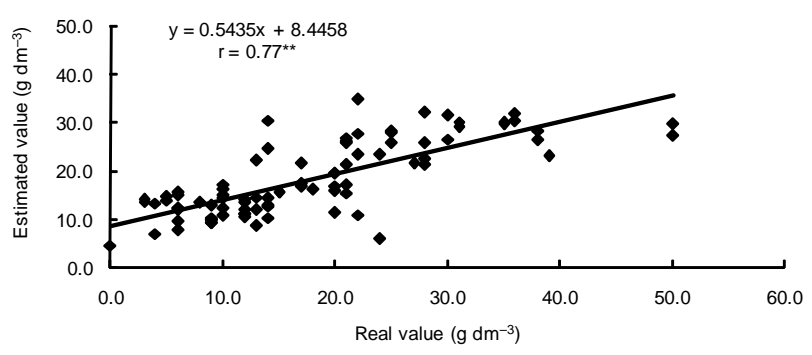

OM - 1 sample each 3.75 ha

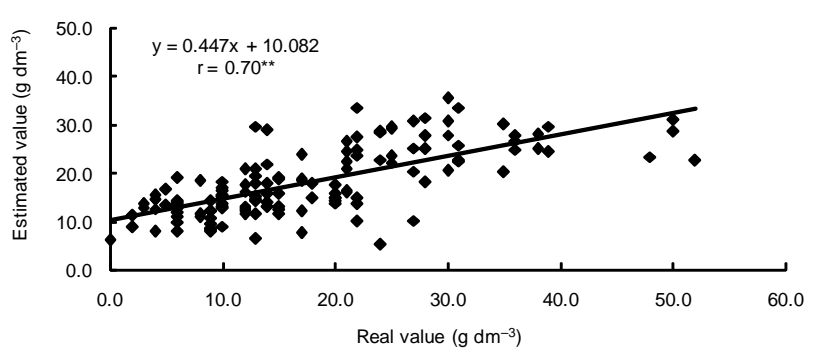

OM - 1 sample each 2.88 ha

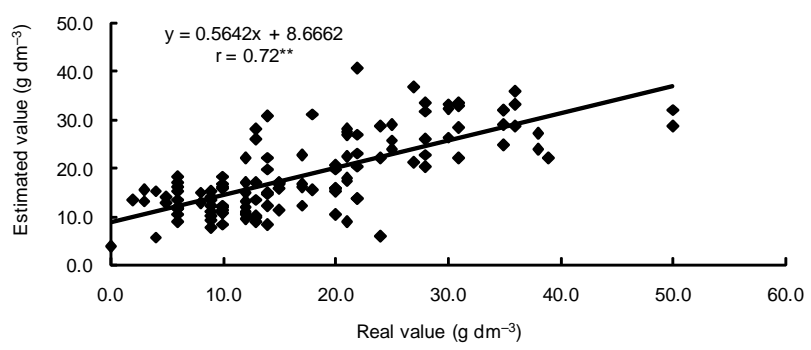

OM - 1 sample each 7.2 ha

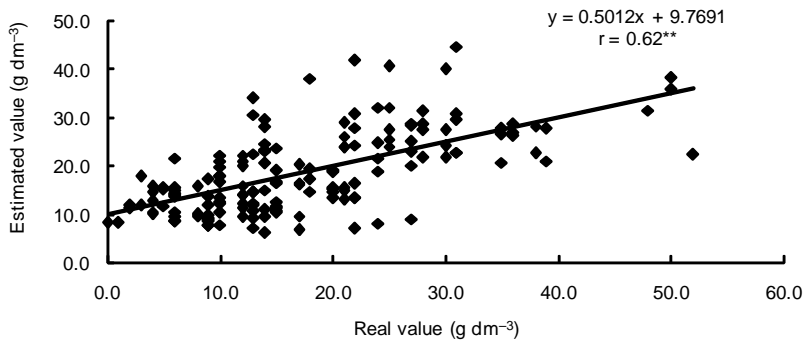

Figure 5 - Regression graphs of estimated values versus observed values for organic matter $(\mathrm{OM})\left({ }^{*} p<0.05 ;{ }^{* *} p<0.01\right)$ obtained through cross-validation at the different sampling scales.

Clay - 1 sample each 2.07 ha

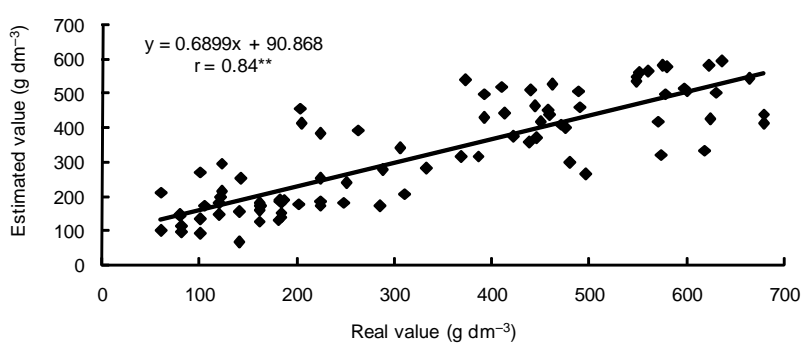

Clay - 1 sample each 3.75 ha

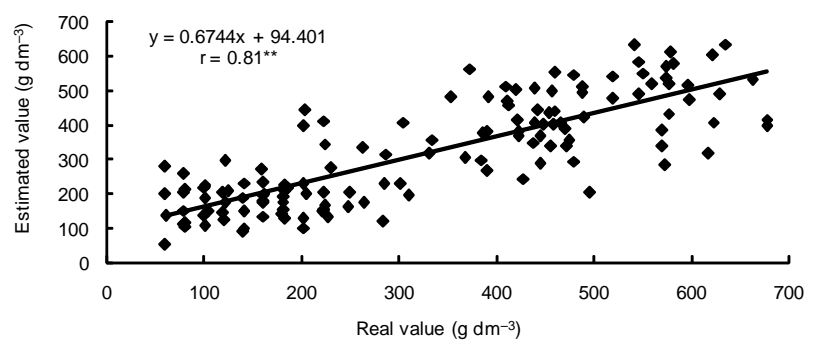

Clay - 1 sample each 2.88 ha

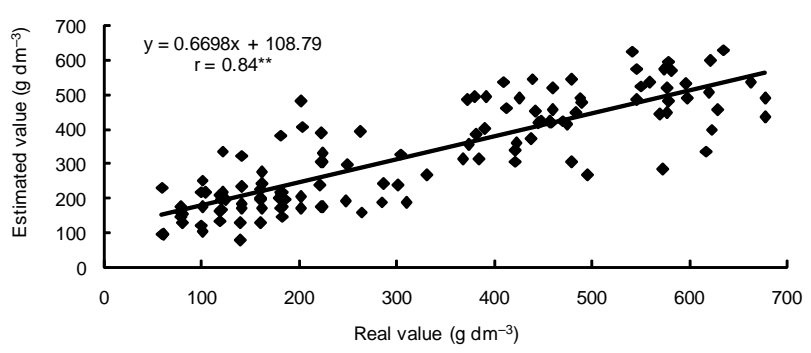

Clay - 1 sample each 7.2 ha

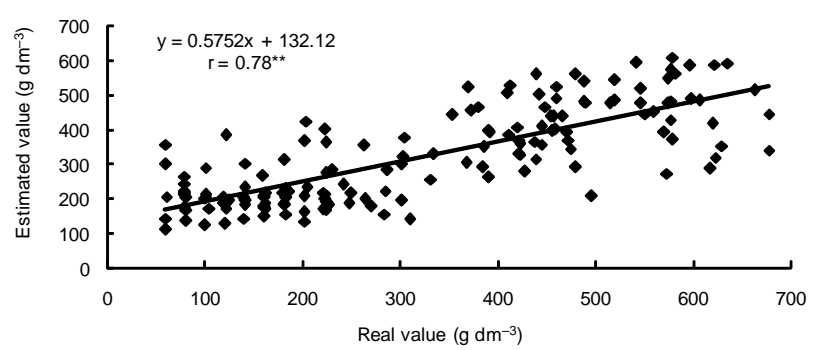

Figure 6 - Regression graphs of estimated values versus observed values for clay ( $\left.p<0.05 ;{ }^{* * *} p<0.01\right)$ obtained through cross-validation at the different sampling scales.

variability, of phosphorus, potassium and base saturation levels. Variable-rate technologies based on soil sample grids can be used only when the optimum grid - mesh is known for the field. In the study-case, it was possible to create reliable maps of organic matter and clay, even at wider sampling scales than 1 sample ha ${ }^{-1}$, however the attributes most often used to determine the recommendations of fertilizer and lime, need a finer sampling.

\section{Acknowledgements}

To FAPESP, 95/6259-6 and 98/3516-6, for financial support.

\section{References}

Burrough, P.A.; Bouma, J.; Yates, S.R. 1994. The state of the art in pedometrics. Geoderma 62: 311-326. 
Cahn, M.D.; Hummel, J.W.; Brouer, B.H. 1994. Spatial analysis of soil fertility for site-specific crop management. Soil Science Society of America Journal 58: 1240-1248.

Camargo, A.O.; Moniz, A.C.; Jorge, J.A.; Valadares, J.M.A.S. 1986. Methods for the Chemical, Mineralogical and Physical Characterization of Soils by IAC. Instituto Agronômico de Campinas, Campinas, SP, Brazil. 90 p. (In Portuguese).

Cambardella, C.A.; Karlenl, D.L. 1999. Spatial analysis of soil version fertility parameters. Precision Agriculture 1: 5-14.

Cohen, J. 1960. A coefficient of agreement for nominal scales. Educational and Psychological Measurement 20: 37-46.

Corá, J.E.; Araujo, A.V.; Pereira, G.T.; Beraldo, J.M.G. 2004. Assessment of spatial variability of soil atributes as a basis for the adoption of precision agriculture in sugarcane plantations. Revista Brasileira de Ciência do Solo 28: 1013-1021. (in Portuguese, with abstract in English).

Costa, A.C.S., M.R. Nanni. 2006. Classification Systems: Brazilian. Encyclopedia of Soil Science. Taylor \& Francis, New York, NY, USA. $234-238$.

Empresa Brasileira de Pesquisa Agropecuária [EMBRAPA]. 1997. Methods of Soil Analyses and Procedures. Centro Nacional de Pesquisa de Solos, Rio de Janeiro, RJ, Brazil. 212 p. (EmbrapaCNPS Documentos, 1). (in Portuguese).

Ferguson, R.B.; Hergert, G.W. 2009. Soil Sampling for Precision Agriculture. University of Nebrasca, Lincon, NE, USA. (Extension EC 154: 1-4).

Flowers, M.; Weisz, R.; White, J.G. 2005. Yield-based management zones and grid sampling strategies: describing soil test and nutrient variability. Agronomy Journal 97: 968-982.

Gotway, C.A.; Ferguson, R.B.; Hergert, G.W.; Peterson, T.A. 1996. Comparison of kriging and inverse-distance methods for mapping soil parameters. Soil Science Society of America Journal 60: 1237 1247.
Mallarino, A.P; Wittry, D. 2004. Efficacy of grid and zone soil sampling approaches for site-specific assessment of phosphorus, potassium, $\mathrm{pH}$, and organic matter. Precision Agriculture 5: 131-144.

Minasny, B.; McBratney, A.B.; Whelan, B.M. 2005. VESPER version 1.62. University of Sydney/Australian Centre for Precision Agriculture, Sydney, AU Available at: http://www.usyd.edu.au/ su/agric/acpa. [Accessed Oct 02, 2008].

Nanni, M.R.; Demattê, J.A.M.; Fiorio, P.R. 2004. Soil discrimination analysis by spectral response in the ground level. Pesquisa Agropecuária Brasileira 39: 995-1006. (in Portuguese, with abstract in English).

Nanni, M.R.; Demattê, J.A.M. 2006. Spectral reflectance methodology in comparison to traditional soil analysis. Soil Science Society of America Journal 70: 393-407.

Raij, B.; Quagglio, J.A. 1989. Methods of Soil Analyses for Fertility. Instituto Agronômico de Campinas, Campinas, SP, Brazil. 31 p. (Boletim Técnico, 8). (in Portuguese).

Soil Survey Staff. Keys to Soil Taxonomy, 1998. Eigth edition, SMSS technical monograph No. 6. Blacksburg, Virginia, pp. 422.

Trangmar, B.B.; Yost, R.S.; Uehara, G. 1985. Application of geostatistics to spatial studies of soil properties. Advances in Agronomy 38: 45-94.

Warrick, A.W.; Nielsen, D.R. 1980. Spatial variability of soil physical properties in the field. 385p In: Hillel, D., ed. Application of Soil Physics. Academic Press, New York, NY, USA.

Received April 27, 2009

Accepted March 14, 2011 